\title{
O cidadão Sócrates e o filosofar numa democracia
}

Roberto Goto*

Resumo: Examinando o julgamento de Sócrates (470-399 a.C.) por Atenas, no contexto da Guerra do Peloponeso (431-404 a.C.), este texto busca as raízes, as razões e os significados de sua condenação nas críticas relações entre o filósofo e seus concidadãos. Neste caso - justamente no que podemos chamar de "o caso Sócrates" - o filósofo aparece (de conformidade com a Apologia escrita por Platão) como um cidadāo-filósofo que desafia o Estado ateniense e incomoda seus concidadãos na medida em que exerce a cidadania como uma forma de filosofar e pratica a filosofia como um direito e um dever de cidadania.

Palavras-chave: filosofar; cidadania; democracia; Sócrates; Atenas.

Socrates as a citizen and the act of philosophizing in a democracy

Abstract: This article examines the trial of Socrates (470-399 B.C.) by Athens, in the context of the Peloponnesian War (431-404 B.C.), searching for the roots, reasons and meanings of his condemnation in the critical relations between the philosopher and his fellow citizens. In this case - exactly in what we can call "the Socrates case" - the philosopher appears (according to Plato's Apology) as a citizen-philosopher who challenges the Athenian State and disturbs his fellow citizens while he exercises citizenship as a form of philosophizing and practices philosophy as a right and a duty of citizenship.

Key words: philosophizing; citizenship; democracy; Socrates; Athens.

A tradição guarda dois episódios em que Sócrates figura, tanto aos olhos da Antiguidade quanto aos nossos, como um cidadão modelar, pelo senso e pela prática do que se pode - e/ou se deve - ter como justo. Um deles data de 406 a.C., quando Sócrates, sorteado para representar sua tribo na Boulé e exercendo a pritania, opôs-se a que os estrategos que lideraram os atenienses na batalha naval das Arginusas fossem julgados em bloco pela acusação de não terem recolhido os náufragos. A lei ordenava que os julgamentos fossem individuais, mas

* Professor do Departamento de Filosofia e História da Educação e membro do Grupo de Estudos e Pesquisas em Filosofia e Educação (Paideia) da Faculdade de Educação da Unicamp, Campinas, SP, Brasil.goto@unicamp.br

Pro-Posições, Campinas, v. 21, n. 1 (61), p. 107-125, jan./abr. 2010 
alguns líderes populares, dentre os quais sobressaía um certo Calixeno, insistiam em que deveria prevalecer a vontade da eclésia, a assembleia que reunia os cidadãos de Atenas. Xenofonte, a quem se deve o relato mais extenso do processo, apresenta os incidentes da seguinte forma:

Entretanto Calixeno havia sido citado judicialmente por Euriptólemo, filho de Peisianax, e por outros, por ter feito uma proposição ilegal. Alguns, no seio do povo, o aplaudiram; mas a multidão se pôs a gritar que era muito estranho que não se deixasse o povo fazer o que lhe aprazia. Neste momento, Licisco tomou a palavra e disse que era preciso julgar tais pessoas da mesma forma que os estrategos, se não retirassem a citação [de ilegalidade]. Novamente a multidão aprovou manifestando-se estrepitosamente eEuriptólemo foi obrigado a retirá-la. Como alguns prítanes declarassem que não colocariam em votação uma moção ilegal, Calixeno se levantou novamente e dirigiu contra eles as mesmas acusaçōes nas quais ele havia implicado os generais, e multidão clamou que era preciso decidir sobre a acusação aos opositores. Os prítanes, aterrorizados, concordaram em colocá-la em votação, com exceção de Sócrates, filho de Sofronisco, que declarou que nada faria que não fosse de conformidade com a lei. (Xénophon, Les Helléniques, livro I, cap. VII, 12-15) ${ }^{1}$

O outro episódio teria ocorrido uns dois anos depois, em 404 a.C., sob a chamada Tirania dos Trinta. Estes, apoiados pelas tropas espartanas comandadas por Lisandro, vencedoras da Guerra do Peloponeso (431-404 a.C.), promoveram um regime de terror que não poupou alguns de seus próprios líderes, como Terâmenes, que tivera papel ativo na denúncia dos estrategos das Arginusas. Em sua Constituição de Atenas (XXXV, 4), Aristóteles descreverá assim o banho de sangue:

Porém, tendo ganho maior domínio sobre a cidade, não pouparam qualquer cidadão, passando, pelo contrário, a executar as pessoas eminentes - seja pela fortuna, seja pelo nascimento, seja pela reputação -, tanto preocupados em suprimir seus temores quanto desejosos de espoliar-lhes os bens. Assim, em pouco tempo, liquidaram não menos de mil e quinhentas pessoas.

Nesse contexto ocorre o caso envolvendo um cidadão de Salamina, chamado Leão, que deveria ser levado a Atenas para - diz o Sócrates da Apologia ${ }^{2}$ atribuída a Platão - morrer.

1. Estas e outras passagens de Les Helléniques foram traduzidas por quem assina o presente artigo.

2. Utiliza-se neste texto a versão publicada sob o título Defesa de Sócrates. 
[...] fui chamado com outros quatro à Rotunda ${ }^{3}$ pelos Trinta e estes nos ordenaram que fôssemos a Salamina buscar a Leão Salamínio para morrer; a muitas outras pessoas eles davam ordens semelhantes, no intuito de comprometer o maior número possível. Nessa ocasião, de novo, por atos, não por palavras, demonstrei que à morte - desculpai a rudeza da expressão não ligo mais importância que a um figo podre, mas a não cometer nenhuma injustiça ou impiedade, a isso sim dou o máximo valor. A mim, aquele governo, poderoso como era, não conseguiu forçar-me a uma injustiça; ao deixarmos a Rotunda, os quatro seguiram para Salamina e trouxeram Leão, mas eu voltei para casa. Bem podia ter morrido por isso, se aquele governo tardasse a cair. (Platão, Defesa de Sócrates, 32c-e)

Ambos os episódios se unem, em certo sentido, na pessoa e na atuação daquele Terâmenes, que participara da batalha das Arginusas na condição de trierarca (isto é, de responsável pela manutenção e pelo aparelhamento de uma trirreme) e havia sido incumbido pelos estrategos de procurar pelos náufragos, juntamente com Trasibulo, outro trierarca, e alguns taxiarcas ${ }^{4}$, a bordo de quarenta e sete naus. Isso, conta Xenofonte n'As helênicas (I, VI, 35), "é o que eles queriam fazer; mas foram impedidos pelo vento e por uma grande tempestade". No processo que se seguiu à volta dos estrategos a Atenas, Terâmenes atuou como acusador, o que lhe valeu, por sua vez, ser acusado posteriormente por Crítias, um dos principais líderes do governo oligárquico, de ter provocado a morte dos estrategos. Terâmenes apresentou a seguinte defesa:

Não, não fui eu que tomei a iniciativa contra eles; eles é que sustentaram que, apesar da ordem que me tinham dado, não recolhi os infelizes náufragos do combate naval de Lesbos 5 . Eu me defendi dizendo que, em seguida à tempestade, não era possível dominar o mar, ainda menos recuperar os corpos, e a assembleia aceitou minha justificativa. Os generais, pelo contrário, pareciam acusar-se a si mesmos. Eles afirmavam que era possível salvar os homens, e no entanto os tinham deixado perecer e partiram com a frota. (Xénophon, Les Helléniques, II, III, 35)

No mesmo discurso, Terâmenes diz concordar com a punição severa dos que quisessem depor os Trinta, mas ressalva que sabia que "se condenássemos à

3. Trata-se do prédio redondo que ficava ao lado do Pritaneu.

4. Os taxiarcas comandavam os contingentes fornecidos por cada uma das dez tribos em que Atenas se dividia.

5. As Arginusas são três pequenas ilhas localizadas ao largo de Mitilene, uma das cidades da ilha de Lesbos. 
morte um Leão de Salamina, o qual era um homem de mérito e reputado como tal, e que nenhum mal havia feito, isso aterrorizaria seus semelhantes" e "o medo fabricaria os adversários de nosso governo" (Xénophon, Les Helléniques, II, III, 39). Condenado a morrer pela ingestão de cicuta, conta-se que atirou uma parte do veneno à maneira do que se fazia num jogo que consistia em lançar o resto de um copo de vinho numa bacia de metal, invocando o nome da pessoa amada; se o jato produzisse um som vibrante, era sinal de que o amor era correspondido ${ }^{6}$. Terâmenes teria dito, então: "Aí está, para o belo Crítias." Xenofonte comenta imediatamente após citar o caso: "Sei bem que estas palavras nada têm de memorável, mas há uma coisa que me parece admirável neste homem: é que em face da morte ele não perdeu nem sua presença de espírito nem seu bom humor" (Xénophon, Les Helléniques, II, III, 56).

Desembaraçados de opositores internos, os Trinta proibiram a entrada na cidade de todos os que não integravam a lista dos cidadãos por eles elaborada, contendo três mil nomes. Trasibulo, refugiado em Tebas, volta a Atenas com setenta homens e, conseguindo decuplicar este número no ataque e na tomada da fortaleza de File, faz guerra às tropas dos Trinta, constituídas pelos três mil cidadãos. Crítias morre na batalha da fortaleza de Muníquia. Restaurada em 403 a.C., com o apoio do rei espartano Pausânias (o qual, adiantando-se a Lisandro, criou as condiçõos para a conciliação das facções atenienses em conflito, do que resultou uma anistia que só não alcançava os Trinta e os executores e apoiadores imediatos de sua política), a democracia toma uma feição "muito conformista no plano institucional", dominada que passou a ser por cidadãos que "pertenciam, em sua maioria, àquele grupo de moderados que cercava Terâmenes e que, muito cedo, tinha-se desligado dos Trinta" (Mossé, 1997, p. 81). Esse grupo se opunha tanto à ampliação do direito de cidadania quanto à sua limitação aos proprietários de bens de raiz. "O povo aferrava-se aos privilégios reconquistados e não tinha intenção de partilhá-los com muita gente", porém "não queria tampouco deles se ver privado" (idem, p. 82).

O curtidor Ânito, patrocinador efetivo ${ }^{7}$ do processo que abaterá Sócrates em 399 a.C., era "um 'moderado' do grupo de Terâmenes" (Mossé, 1997, p. 84) e, embora as feridas custassem a cicatrizar, o que significa que os "antigos rancores suscitados pela política dos Trinta demoraram muito a se extinguir" (idem, p. 82), o processo contra Sócrates, vindo "desses homens que pretendiam manter a democracia ateniense nos limites tradicionais e conformistas", não pode, no entender da historiadora que vimos citando, ser considerado, "de modo algum", como "uma desforra de democratas exaltados contra o amigo de

6. Cf. nota 7l da edição de Les Helléniques, p. 42I.

7. O autor, na acepção formal, foi Meleto.

Pro-Posições, Campinas, v. 21, n. 1 (61), p. 107-125, jan./abr. 2010 
Crítias e Cármides" (idem, p. 84). Este juízo ecoa o de Moses Finley (1991, p. 83), para quem não havia predisposição para um linchamento político, nem "indícios de que os ânimos estivessem exaltados. Ninguém estava criando um mártir. Isso veio depois."

$\mathrm{Na}$ falta de motivaçôes políticas em sua acepção mais estrita, restariam os motivos de ordem pessoal. Assim, Ânito teria patrocinado o processo contra Sócrates porque este havia dito "certo dia que, uma vez que fora levado às primeiras dignidades da República, não ficava bem elevar o filho ao mister de tanoeiro", como relata Xenofonte em sua Apologia de Sócrates (III, 29), uma das muitas que passaram a ser compostas então. O próprio Crítias, ainda segundo Xenofonte (nos Ditos e feitos memoráveis de Sócrates, livro I, cap. II, 29-39), teria se ressentido contra Sócrates, proibindo por lei que ensinasse retórica, porque o filósofo o teria advertido "ante numerosa assistência" dizendo que "Crítias lhe parecia ter tal ou qual semelhança com um porco, pois queria esfregar-se em Eutidemo como se esfregam os porcos nas pedras" (Memoráveis, I, II, 30-31).

É possível, além disso, atribuir todo o processo contra Sócrates a razão nenhuma, isto é, ao mero azar, sobretudo se enfatizarmos - como o faz M. Finley ${ }^{8}$ - uma passagem da famosa carta sétima de Platão, em que este se refere à agitação decorrente da queda dos Trinta:

[...] ocorreram, então, fatos revoltantes, não sendo assim, de admirar que passassem da conta os atos de vingança individual, muito embora os exilados, de retorno, procedessem com certa moderação. Mas, por um azar inexplicável, algumas pessoas de influência levaram aos tribunais esse nosso amigo, Sócrates, assacando-lhe uma acusação odiosa que ele absolutamente não merecia. Uns o perseguiram por impiedade e outros o condenaram, com o que fizeram morrer o homem que se recusara a tomar parte na prisão ímpia de um dos seus companheiros de exílio, numa época em que eles próprios, exilados como aquele, se encontravam em situação inferior. (Platão, Sétima Carta, 325b-d; grifo meu)

8. Cf. "Sócrates e Atenas", in Aspectos da Antiguidade, p. 82-83: "Permanece a pergunta: Por que Sócrates foi julgado em 399? Minha resposta é tão pouco sensacional quanto poderia ser, e é precisamente a resposta que nos dá a carta atribuída a Platão: Sócrates foi acusado por algum acaso". Em suma, segundo o historiador, foi uma "combinação casual de história e fatores pessoais a responsável pela grande tragédia de 399. Não era inevitável que Sócrates fosse julgado e executado. Mas, quando foi acusado em 399, tornou-se imediatamente provável que a atmosfera que vinha se formando desde 43 I viesse a destruí-lo".

Pro-Posições, Campinas, v. 21, n. 1 (61), p. 107-125, jan./abr. 2010 
Os episódios em que se mostra de forma emblemática o senso socrático de legalidade e de justiça contrastam entre si pelo contexto: o primeiro se dá num regime democrático; o segundo, sob um domínio oligárquico. Ambos se equiparam, entretanto, como atos de resistência ao arbítrio, aproximando-se e unindose por um elo que a coerência do protagonista - ela também emblemática fornece. A arbitrariedade não é menor no primeiro caso somente porque praticada pela maioria da assembleia popular. No mínimo, trata-se de um erro, que custará à cidade a perda de seis estrategos (dentre os quais o filho que Péricles teve com a concubina Aspásia) e que Atenas reconhecerá, punindo os líderes que induziram a massa popular a votar pelo julgamento em bloco dos acusados.

Os atenienses não tardaram a se arrepender, e decretaram que aqueles que haviam enganado o povo seriam acusados e forneceriam fiadores até o momento do julgamento. Calixeno constava entre eles; quatro outros foram acusados juntamente com ele e aprisionados por seus fiadores. Mas em seguida, graças a um motim em que morreu Cleofonte ${ }^{9}$, eles fugiram antes de serem julgados. Calixeno retornaria posteriormente a Atenas com os exilados do Pireu; execrado por todos, morreu de fome. (Xénophon, Les Helléniques, I, VII, 35)

Já a oposição de Sócrates aos Trinta, em particular ao ex-"discípulo" Crítias, tio-avô ${ }^{10}$ de Platão, deveria ser reconhecida como um serviço e um preito aos democratas - e à própria democracia, enquanto aparato legal -, na medida em que o filósofo, ao recusar-se a cumprir uma ordem flagrantemente injusta, compromete-se concretamente ("por atos, não por palavras") com aqueles que os tiranos perseguiam e queriam exterminar. Em ambos os casos, a resistência implicava o risco de ser morto: em 406, de sofrer a mesma pena imposta aos estrategos; em 404, de ir juntar-se aos mais de mil e quinhentos mortos contabilizados a posteriori por Aristóteles. A contabilidade de Sócrates, por sua vez, não ignora os dois episódios quando ele se defende das denúncias de Meleto, Ânito e Lícon: indiretamente, na medida em que visava ao cumprimento da lei

9. Fabricante de liras, incluído por Aristófanes entre os demagogos que passaram a atuar em Atenas na segunda metade do século $\vee$ a.C., caracterizados por "sua falta de compostura, sua má educação e a tenacidade com que bajulavam o povo e se adiantavam a seus desejos". Os outros eram Cléon, curtidor, e Hipérbolo, produtor de lâmpadas (cf. Mossé, 2004, p. 84).

10. Segundo Diógenes Laércio (Vidas e doutrinas dos filósofos ilustres, livro III, "Platão", I), Crítias era irmão de Gláucon, pai de Perictione, a mãe de Platão. A família teria Sólon entre os ascendentes: Crítias e Gláucon seriam bisnetos de Diopides, irmão de Sólon. 
e/ou à preservação do que é justo, sua participação em ambos era parte da missão de que se considerava investido e que o fazia exortar os concidadãos a buscarem a areté. Nesses casos, justamente, ele os educava politicamente pela ação, pelo exemplo - mais por atos do que por palavras.

Esse "politicamente" alude à política em sua acepção mais ampla - porém não menos concreta e complexa - de ação do membro da pólis, de sua convivência com os concidadãos, o que compreende necessariamente o trabalho socrático com os valores e os conceitos, simultaneamente ético e epistemológico. Essa política lato sensu não entra em contradição com a recusa voluntária de participar da política administrativa e judicial da cidade, ou seja, da política em seu sentido mais restrito de "negócios públicos", os quais carregavam o perigo daquela morte e eram associados, pelos contemporâneos, a uma categoria mais ou menos específica: a dos "políticos”, evidentemente. Tal abstenção dos "negócios públicos" constitui, na verdade, condição para o exercício daquela política de sentido mais amplo (ético-epistemológica, digamos), na medida mesma em que o filósofo, assim fazendo, resguarda-se do risco de ser apanhado e abatido no fogo cruzado das facções em luta.

No entanto, dois aspectos tornam o quadro bem mais complexo. Um deles é o fato de que a abstenção dos "negócios públicos" não é nem pode ser total. Ao contrário, a participação na política stricto sensu é exigida como pressuposto e requisito da cidadania, ou seja, como parte do cumprimento do dever cívico e da busca e do exercício da areté. Ela inclui a atuação do filósofo não só nos episódios citados, mas também na própria Guerra do Peloponeso, como soldado da infantaria pesada, isto é, como hoplita. Compreende-se que, neste sentido, Sócrates procure encorajar Cármides a, como se diz hoje, "entrar na política": sua tentativa de persuadi-lo a tanto, como se vê em Xenofonte (Memoráveis, livro III, cap. VII, 1), integra seu trabalho cotidiano de contribuir para a conquista de uma areté que reverta em benefício tanto do indivíduo quanto da pólis, uma vez que julga Cármides "homem de grande mérito e muito superior a todos os políticos do tempo", exortando-o, portanto, a "concentrar todos os esforços" sobre si mesmo e a "não esquecer o Estado", se lhe puder ser útil; dessa forma, fará prosperar a coisa pública e prestará "imenso serviço não somente aos cidadãos em geral” como aos amigos e a si próprio (idem, III, VII, 9).

$\mathrm{O}$ outro aspecto é aquele que acrescenta ou empresta à política lato sensu do filósofo-cidadão uma conotação um pouco mais forte do que aquela que ela permite entrever à primeira vista: a abstenção da escrita e a dedicação à palavra falada, ao diálogo vivo, significam que Sócrates foi um filósofo que agiu pela fala e por ela influenciou seus concidadãos - e se um indivíduo se define como político na medida em que age e influencia os demais por meio da palavra viva, 
em ato (isto é, a fala), Sócrates foi sem dúvida o mais público, o mais político, o mais cidadão de todos os filósofos. E, embora só possamos ter e construir imagens dele a partir do que se escreveu a seu respeito - o que é inevitável -, a imagem que predomina sobre as demais - ou as monopoliza - é a de um filósofo em ação e sobretudo da ação: um cidadão que agiu sobre outros cidadãos falando, conversando e discutindo com eles; um cidadão que sustentou e defendeu a palavra falada, viva (em contraposição à palavra escrita, que tinha na conta de morta), como meio de ação na e para a pólis. É neste específico sentido que cabe pensar numa retórica socrática, paralela à sofística e dela distinta, e se compreende porque Crítias e Cáricles, aproveitando-se da função de nomotetas $^{11}$ que desempenhavam na Tirania dos Trinta, proíbem a Sócrates o "ensino da oratória" (Xenofonte, Memoráveis, I, II, 31): no caso, falar não é discursar e apresentar argumentos para vencer um debate na assembleia e persuadir ouvintes, mas, justamente, agir - no pleno significado do agir político (e democrático) de denunciar o arbítrio e a violência e criticar seus autores.

Haviam os Trinta feito morrer grande número de cidadãos dos mais ilustres e desgarrado outros tanto da trilha da justiça. Disse Sócrates, de uma feita, que muito estranharia que o guarda de um rebanho que fizesse seus bois diminuírem de número e emagrecerem, não se reconhecesse mau pastor. Mas que mais estranharia ainda se um homem colocado à testa de um Estado e cujos cidadãos tornasse menos numerosos e piores não se envergonhasse de seus atos e não conviesse ser mau magistrado. Indo estas palavras ter aos ouvidos de Crítias e Cáricles, estes chamaram Sócrates à sua presença, mostraram-lhe a lei e proibiram-lhe toda palestra com os jovens. (Xenofonte, Memoráveis, I, II, 32-33)

Essa retórica pode ser confundida eventualmente com a dos sofistas, porque pode parecer que está a serviço de qualquer ideia, tanto a democrática quanto a oligárquica. A retórica sofística, com efeito, pode ser considerada inclusiva: recolhe e admite todo ponto de vista, que ela se dispõe e se prontifica a defender com o mesmo brilho, porque é acima de tudo funcional e operacional, numa palavra, técnica; o critério a que se submete é o da eficácia e não o da verdade do argumento, uma vez que relativiza, suspende ou nega, ceticamente, a possibilidade de um conhecimento verdadeiro, que diga o real. O que se pode chamar de retórica socrática póe-se, por contraste, numa perspectiva situada para além das posições políticas (stricto sensu) em jogo e em conflito, não avalizando os mecanismos do regime democrático tal como praticado na épo-

II. "Legisladores" ou, mais exatamente, revisores de leis. 
ca, porém tampouco - muito menos - aderindo ao oligárquico; visa ao conhecimento (à epistéme) e à prática de uma areté e de um ideal de justiça que o filósofo não vê plenamente realizados em nenhum desses regimes.

Por outro lado - e talvez este seja o lado mais importante -, trata-se de uma retórica negativa, de uma não-retórica, mesmo de uma antirretórica: a ação (política) pela palavra (do filósofo) não se dá de forma estreitamente discursiva, mas dialógica, o que significa que, se há um discurso, este não é posse ou propriedade de um sujeito que disserta sobre um assunto e a respeito dele defende seu ponto de vista, expondo um argumento com introdução, desenvolvimento e conclusão - e que, portanto, precisa ser produzido (escrito) e encontra-se pronto antes de ser exposto. O diálogo pressupóe e implica um compartilhamento do logos, que neste caso, a rigor, não pertence a ninguém ${ }^{12}$ : não possuído nem dominado por alguém em particular, ele circula por entre os sujeitos, na forma - quando muito - de um "discurso" fragmentado e entrecortado, improvisado e imprevisível, "composto" coletivamente por perguntas e respostas, por pausas, reticências e silêncios, por invectivas e evasivas etc., sem começos ou finais preestabelecidos. Se o agonismo retórico ocorre como que pela oposição entre blocos, o dialógico se dá de forma fluida e fragmentada, golpe por golpe, passo a passo. Em ambos os casos, as imagens preservadas e legadas pela tradição não são nada amenas, nada light - como a recolhida e narrada por Diógenes Laércio uns seiscentos ou setecentos anos após a morte de Sócrates:

Frequentemente sua conversa nessas indagaçôes tendia para a veemência, e então seus interlocutores golpeavam-no com os punhos ou lhe arrancavam os cabelos; na maior parte dos casos Sócrates era desprezado e ridicularizado, mas tolerava todos esses abusos pacientemente. Incidentes desse tipo chegaram a tal ponto que certa vez, suportando com a calma habitual os pontapés que recebera de alguém, a uma pessoa que manifestou admiração por sua atitude o filósofo respondeu: "Se eu recebesse coices de um asno, levá-lo-ia por acaso aos tribunais?" (Vidas e doutrinas dos filósofos ilustres, livro I, cap. 5, 21)

Esta passagem antológica revela o tipo de sociabilidade que vigorava e predominava em Atenas e que hoje nos inclinamos a classificar como fazendo parte do "jogo democrático", o que implica reconhecer que ele não constitui apenas o espaço civil e civilizado em que contendas e confrontos se resolvem via

12. Cf. Bakhtin ( 198I, p. 94): a "concepção socrática da natureza dialógica da verdade" pressupõe que a "verdade não nasce nem se encontra na cabeça de um único homem; ela nasce entre os homens, que juntos a procuram no processo de sua comunicação dialógica". 
consenso, imperando aí a cortesia e o respeito mútuos e a harmonia dos contrários, mas inclui as expressões mais francas, vulgares, mesquinhas e grosseiras, assim como agressóes, tanto verbais quanto físicas.

Por outro lado, o episódio é sintomático de disposições e precauções que aproximam Sócrates dos ideais que identificam e tornam sublime o "jogo democrático": de forma mais explícita, sua sistemática e permanente recusa em recorrer à violência física, o que, entretanto, não significava transigência e delicadeza. "Todos se espantavam de vê-lo", escreve Plutarco sobre Alcibíades, "jantar com Sócrates, exercitar-se com ele, compartilhar de sua tenda - com Sócrates, tantas vezes duro e intratável para com outros que o requisitavam, não raro distante e desdenhoso" (Vidas Paralelas, "Alcibíades", 4).

Já mais tacitamente, é possível ler no mesmo trecho de Laércio a preocupação socrática em fazer valerem, na política stricto sensu da cidade, os princípios da ética que o filósofo-cidadão vivia e praticava tanto quanto professava: processar o interlocutor enfurecido e escoiceador seria um procedimento inútil, pois, se ele nada quis aprender por meio do diálogo, tampouco aprenderá ao ser submetido ao tribunal. Implícita nesta conclusão está a ideia de uma pólis que, por meio das próprias leis e de sua execução, procure educar os cidadãos, como Sócrates reivindica, perante Meleto, ao defender-se da acusação de corromper os jovens:

Não; ou não corrompo, ou, se corrompo, é sem querer [...]. Se, porém, corrompo sem querer, a lei não manda trazer-me aqui por semelhante erro involuntário, mas tomar-me de parte, ensinar-me, ralhar comigo; evidentemente, depois de aprender, deixarei de fazer o que sem querer ando fazendo. (Platão, Defesa de Sócrates, 26a)

Em seu julgamento, cumpriu-se e venceu o movimento contrário: foram os princípios e mecanismos da política stricto sensu, os quais se valiam da violência e da censura, que se impuseram àquela política lato sensu da ação pela palavra, educativa e compreensiva, terminando por calá-la definitivamente pela eliminação física de seu protagonista. E, dessa forma, se Sócrates se esforçou por abster-se da política de Estado, esta não se absteve dele - sobretudo não se absteve de castigá-lo e matá-lo, atuando de um modo completamente oposto e contrário ao que ele próprio adotava em relação aos que o insultavam e agrediam. Como desconsiderar, assim, o caráter ou aspecto político do processo contra Sócrates? Se as acusações não expressaram um movimento de revanchismo ou linchamento político, mas foram motivadas por rancores e ressentimentos pessoais - o que remete a explicação a uma instância psicológica -, de qualquer forma elas só prosperaram e lograram êxito na medida em que encontraram um 
meio politicamente propício: se eram individuais em sua origem, essas vozes clamando pela morte do filósofo encontraram no espaço coletivo (político) da pólis o eco que reivindicavam, o que implica admitir que as vozes que calaram a de Sócrates foram, afinal, as vozes dos que administravam então os destinos da cidade.

Mas convém perguntar explicitamente: o que fez Sócrates para ter contra si essas forças (políticas, afinal)? Tratou-se, diz Claude Mossé (1990, p. 151), de um "processo imposto a um homem que pensava diferentemente". Cabe, entretanto, salientar o advérbio (o "diferentemente") antes que o verbo ("pensava"), podendo-se - ou mesmo devendo-se - substituir o último por "fazia". Justamente, se se quer levar em consideração o sentido político do processo, ao mesmo tempo respeitando a especificidade do caso Sócrates, importa menos o que o filósofo-cidadão pensava, ou seja, suas opiniōes, do que sua ação, ou o modo como agia. Mais relevante que o conteúdo da fala é a dimensão mesma do falar, inclusive porque, no caso, tratava-se de um conteúdo negativo, isto é, vazio, que dizia ou queria dizer apenas e essencialmente uma coisa: que aquele que fala nada sabe realmente, ou somente sabe que nada sabe.

As opiniões (inevitavelmente políticas) de Sócrates, incluindo aquelas que os intérpretes se inclinam a avaliar como simpáticas ao regime oligárquico, mais precisamente o espartano, ele as expressava no contexto de suas relações privadas: "As críticas formuladas por Sócrates não saíam, entretanto, do círculo de seus íntimos" (Mossé, 1990, p. 95). Se alcançavam o espaço público, é de se supor que aí se expunham, em rigoroso pé de igualdade com outras opiniões, a sofrer ou submeter-se a toda espécie de crivo, escrutínio, crítica, ataque, zombaria etc., da parte de outros cidadãos. Trata-se, na verdade, de algo que vai além da mera suposição: As nuvens, de Aristófanes, são a imagem vívida não só do que se podia satirizar a (em) (des)respeito das ideias atribuídas a Sócrates, mas do que efetivamente se satirizou, no movimento do "jogo democrático". E, na medida em que se podiam reduzir assim a pó de traque tanto as ideias quanto a persona e a reputação de Sócrates, não faz sentido - dum ponto de vista racional, evidentemente - que o filósofo pudesse representar (ou ser interpretado como) uma ameaça temível à manutenção do Estado ateniense. Em suma, por que se quereria ou se precisaria matar um homem que, pelo que pensava, podia ser facilmente ridicularizado e neutralizado, tratado como palhaço? ${ }^{13}$ Matá-lo, em tal caso, para desmoralizar suas opiniōes e anular seus efeitos, seria o mesmo que chutar cachorro morto...

13. "Onde quer que a autoridade ainda pertença aos bons costumes, onde quer que não se 'fundamente', mas sim ordene, o dialético aparece como uma espécie de palhaço: ri-se dele, mas não se o leva a sério. - Sócrates foi o palhaço que se fez levar a sério", escreveu Nietzsche (2000, p. 20; grifo do autor). O que não significa que tenha sido levado a sério pela plebe de que

Pro-Posições, Campinas, v. 21, n. 1 (61), p. 107-125, jan./abr. 2010 
Que peso, afinal, tiveram as opiniōes de Sócrates na iniciativa de o levarem a julgamento? Para o Sócrates da Apologia creditada a Platão, praticamente nenhum. Não é o que pensa, mas o modo como age que irrita os acusadores: é porque sua fala em praça pública embaraça, incomoda e espicaça os cidadãos como um tavão (Platão, Defesa de Sócrates, 30e), destruindo reputações de sabedoria e fazendo com que os interrogados acabem, por si mesmos, provando que "fingem saber, mas nada sabem" (idem, 23e). As acusações de impiedade, de criação de novas divindades e de corrupção dos jovens são, no fundo, apenas cortina de fumaça: Meleto, Ânito e Lícon se mancomunam para atacar Sócrates porque tomam as dores daqueles ${ }^{14}$ que ele submetera ao seu interrogatório inquiridor (idem, 24a). A dialética, em tal caso, não consiste em apresentar razões, mas no seu oposto - em subtraí-las do adversário -, como anota, aliás, o próprio Nietzsche (2000, p. 21): “O dialético lega a seu adversário a necessidade de mostrar que não é um idiota: ele o deixa furioso, mas ao mesmo tempo desamparado".

Portanto, segundo a tese que o Sócrates da Apologia platônica apresenta e sustenta do começo ao fim de sua defesa, inalterável e inabalavelmente, é o procedimento que adota no cumprimento de sua missão que atiça "a calúnia e o rancor de tanta gente" (Defesa de Sócrates, 28a). É também ao procedimento dos concidadãos que ele visa, ao "andar por aî" procurando persuadi-los, "moços e velhos, a não cuidar tão aferradamente do corpo e das riquezas, como de melhorar o mais possível a alma" (ibidem, 30a). Igualmente, era seu agir e proceder que desmentia que pudesse ser ímpio ou corromper a juventude, pois sua prática investigativa estava a serviço do deus Apolo e ele, Sócrates, "nunca" foi "mestre de ninguém" (ibidem, 33a), não se podendo, portanto, atribuir-selhe nenhum discípulo em sentido próprio: importa-lhe desempenhar sua tarefa, gratuitamente, estando

igualmente à disposição do rico e do pobre. [...] Se algum deles vira honesto ou não, não é justo que eu responda pelo que jamais prometi nem ensinei a ninguém. Quem afirmar que de mim aprendeu ou ouviu em particular alguma coisa que não todos os demais, estais certos de que não diz a verdade. (ibidem, 33b)

fazia parte congenitamente e a quem ele teria permitido ascender por meio da dialética. Não é plausível que somente a "boa sociedade" aristocrática imaginada por Nietzsche, que recusava como "indecoroso" o ato de "mostrar os cinco dedos" - apresentar razões e argumentos" -, pudesse rir do filósofo do "pensatório" aristofânico. A possibilidade e o direito de não levá-lo a sério, e ainda por cima de achincalhá-lo e escoiceá-lo, estavam ao alcance de todos, democraticamente.

14. Respectivamente: os poetas; os artesãos e os políticos; os oradores. 
Os que passam por "discípulos" de Sócrates são os que frequentavam livremente o seu círculo, sem quaisquer obrigaçôes pecuniárias, pedagógicas ou curriculares, tanto da parte do "mestre" quanto do "aluno", com a provável exclusão também - se vale a narrativa de Alcibíades como personagem do Symposion escrito por Platão - de um compromisso entre o erasta e o erômeno. Crítias, a propósito, será incluído pela tradição não só entre os adeptos da sofística como será considerado ele próprio um sofista, notadamente pela composição de um drama intitulado Sísifo, em que o personagem-título afirma crer que um "homem de mente muito sagaz e sutil inventou para os homens o temor dos deuses, a fim de que houvesse algo para aterrorizar os maus ainda que agissem, falassem ou pensassem em segredo" (apud Guthrie, 1995, p. 226). Por outro lado, ele não foi apenas o mais sanguinário dos Trinta; foi também o que, antes disso, exilado na Tessália, aí "fomentou uma revolta dos 'penetas', camponeses dependentes, contra seus senhores" (Mossé, 2004, p. 80). Quanto a Alcibíades, que se comportava como um camaleão, pela "facilidade com que se adaptava a outros modos de vida" (Plutarco, Vidas Paralelas, "Alcibíades", 23), as palavras de Sócrates "tocavam fundo a boa natureza do jovem, agitavam-lhe o coração e não raro o faziam desmanchar-se em pranto", mas em outras ocasiōes "abandonava-se aos aduladores que lhe vinham propor divertimentos e escapava a Sócrates" (ibidem, 6).

Toda a defesa que Sócrates sustenta ante seus juízes, a começar pela recusa da eloquência, do "estilo florido" dos discursos forenses (Defesa de Sócrates, 17b-c), apela tácita mas insistentemente para um julgamento que tome em conta sua ação mais do que a opinião, sua política ético-epistemológica mais do que sua oratória pedagógica. Como qualificar esse agir, senão como essencialmente democrático? Com suas retórica e dialética negativas, ele não só bate metaforicamente - como, nos termos de hoje, "dá a cara para bater"; portanto, apanha, não raro, literalmente. Em tal prática, a "liberdade de expressão" como conquista democrática alcança a realização de sua substância política: na ágora da pólis, ganha existência concreta. Se se define a sociedade democrática como sociedade aberta $^{15}$, não há filosofia que possa ser mais conforme - mais igual -

15. Popper (1974, v. I, p. 144) ressalva Sócrates de sua crítica ao historicismo e ao totalitarismo, caracterizando-o como um "bom democrata" que "considerou de seu dever expor a incompetência e charlatanaria de alguns líderes democráticos de sua época", e seu "corajoso comportamento sob o regime dos Trinta Tiranos" não permite pensar que "sua crítica dos líderes democráticos fosse inspirada por qualquer coisa parecida com inclinações antidemocráticas". Já no que respeita à missão socrática, Popper (ibidem, p. 145) considera que pode conter um aspecto autoritário, na medida em que o "deseducado" parece precisar "de uma autoridade que o desperte", mas "este elemento de autoritarismo foi admiravelmente equilibrado no ensinamento de Sócrates, pela ênfase em que a autoridade não deveria reclamar mais do que isto". Sócrates poderia ter "justificado sua missão de despertar o povo de seu sono dogmático", dizendo: "Toda autoridade que tenho repousa apenas em meu conhecimento de quão pouco sei".

Pro-Posições, Campinas, v. 21, n. 1 (61), p. 107-125, jan./abr. 2010 
à democracia que essa filosofia que na verdade não contém nada, nenhuma doutrina, nenhuma escrita, a não ser uma prática, uma ação que se efetiva pela fala, abrindo espaço em meio aos preconceitos mediante o trabalho de "interrogar, examinar e confundir" (ibidem, 29e), mantendo-se ela própria sempre aberta, já que, no fim das contas, não afirma nada - apenas que nada sabe...

A missão apolíneo-socrática pode não ser do agrado - pelo contrário, é motivo de extenso e intenso desagrado - da maioria dos cidadãos, mas não fere as leis da cidade ${ }^{16}$. Insistindo nela, Sócrates obedece ao deus Apolo (ibidem, 30a) e assim dá mostra de uma manifesta piedade, que refuta, aliás, a primeira das acusações: esta escolha pode ser vista como uma reedição daquela outra, em que o prítane optou por ficar do lado do que dispunha a lei, recusando-se a referendar a vontade popular, a qual favorecia o julgamento em bloco dos estrategos. $\mathrm{Na}$ medida em que a missão corresponde a um desígnio divino que concorre para o bem da cidade, persistir nela é evitar que ela própria, a pólis, cometa um ato ímpio:

Neste momento, Atenienses, longe de atuar na minha defesa, como poderiam crer, atuo na vossa, evitando que, com a minha condenação, cometais uma falta para com a dádiva que recebestes do deus. Se me matardes, não vos será fácil achar outro igual, outro que - embora seja engraçado dizê-lo - por ordem divina se aferre inteiramente à cidade, como a um cavalo grande e de raça, mas um tanto lerdo por causa do tamanho e precisando de um tavão que o espevite; parece-me que o deus me impôs à cidade com essa incumbência de me assentar perto, em toda parte, para não cessar de vos despertar, persuadir e repreender um por um. [...] Bem pode ser que, aborrecidos como quem dormia e foi despertado, deis ouvidos a Ânito e, repelindo-me, me condeneis levianamente à morte; depois, passareis o resto da vida a dormir, salvo se o deus, cuidadoso de vós, vos enviar algum outro. (ibidem, 30d-31a)

Sócrates, por sua vez, está plenamente consciente de que é a pólis ateniense que lhe propicia as condições para o exercício de sua missão, embora esta desa-

16. Não há menção explícita na Apologia de que alguma lei a proíba. Portanto, é bem difícil interpretar a advertência de Sócrates - no sentido de que seguirá com sua missão, mesmo que os juízes the ordenem que desista dela - como um ato de "desobediência civil", conceito que, além disso, se aplicado ao caso, importa em anacronismo. Cabe mais pensar que Sócrates tenha tomado a presuntiva e hipotética ordem como uma predisposição arbitrária, a qual, pelo precedente representado pelo episódio das Arginusas, correria, ela sim, o risco de afrontar não só a lei como o costume da cidade. Igualmente difícil é ver, assim, alguma contradição entre este Sócrates e o do Críton, em que ele dialoga com as Leis da cidade e lhes presta como que um juramento de fidelidade.

Pro-Posições, Campinas, v. 21, n. 1 (61), p. 107-125, jan./abr. 2010 
grade àquela, e o que diz para repelir a ideia de um exílio como alternativa à pena de morte pode bem ser tomado como uma homenagem crítica à democracia de Atenas:

Muito amor à vida deveria eu ter para ficar tão estúpido que não compreendesse que, se vós, sendo meus concidadãos, não pudestes aturar minhas conversas e assuntos, tão importunos e odiosos para vós, que neste momento vos estais procurando livrar deles, outros hão de aturá-los melhor? Que esperança, Atenienses! (idem, 37c-d)

Resumindo: Sócrates prefere continuar vivendo em sua cidade, pois se a situação para ele em Atenas é ruim, muito pior seria em outro lugar qualquer; enquanto consentirem que viva, prosseguirá tentando despertar os concidadãos para a vida justa; julga que, assim agindo, contribui para o bem da pólis, a despeito da oposição e do ódio que muitos cidadãos lhe votam; é assim que exerce sua cidadania, publicamente, não ofendendo as leis da cidade, mas, admite, importunando e irritando cada cidadão ao tentar persuadi-lo a "cuidar menos do que é seu que de si próprio, para vir a ser quanto melhor e mais sensato, menos dos interesses do povo que do próprio povo" (ibidem, 36c). Já que insiste em permanecer na cidade, mesmo expondo a extremo perigo sua vida, dá a entender que tal "projeto" se volta para a democracia tal como existe concretamente e só tem sentido se aí levado a efeito; portanto, oferece aos atenienses a oportunidade de aperfeiçoarem sua democracia e não a exigência de que a substituam por outro regime ou sociedade. Também esse "projeto" é negativo, na medida em que se dá imediatamente - sem distância entre o pensar e o fazer - como prática inscrita nas condições reais e não projeta no horizonte político a imagem de um Estado ideal. No máximo, permanece e se detém no patamar crítico, dando a ver uma imagem em negativo da sociedade existente, ou seja, daquilo que lhe falta.

Agindo democraticamente (inclusive neste sentido de que, ao imiscuir-se entre os cidadãos, nunca recorre à violência nem ao que hoje denominamos de "autoritarismo", mas sempre à persuasão, ao convencimento pela palavra), Sócrates recusa-se, porém, a ser um demagogo, ou seja, a bajular e seduzir a massa, mesmo quando disso depende sua vida. No lugar de "suplicar aos juízes com lágrimas copiosas, de trazer, para melhor movê-los à piedade, os filhos, outros parentes, muitos amigos", ele não faz "nada disso" (ibidem, 34c) e, após tomar conhecimento da condenação e dizer que se conformava com ela, pois não era "fato inesperado" (ibidem, 36a), propõe que a sentença em seu caso seja a honra de ser alimentado no Pritaneu (ibidem, 36d-37a), uma vez que nenhum crime praticou - todas as acusaçõos não passam de calúnias - mas, ao contrário, presta à cidade o serviço inestimável que é exercer a missão que Apolo 
lhe confiou.

Dois “cenários", como se diz hoje, podem ser imaginados: 1) a tese de Sócrates não convence os juízes, e ele é condenado pelas acusaçôes originais; 2) a tese vence, refuta as acusações, mas não reverte a condenação - é por rancor mesmo que se condena Sócrates, porque a cidade está farta dos interrogatórios que empreende em nome de Apolo e porque, além disso, ele se comporta arrogantemente, sem qualquer humildade. Em ambas as hipóteses, Sócrates fracassa em fazer valer a razão do filósofo-cidadão sobre a demagogia: "Perdi-me por falta, não de discursos, mas de atrevimento e descaro, por me recusar a proferir o que mais gostais de ouvir, lamentos e gemidos, fazendo e dizendo uma multidão de coisas que declaro indignas de mim, tais como costumais ouvir dos outros" (ibidem, 38d-e).

Quanto a Atenas, perde a oportunidade de preservar e manter consigo aquele que, muito mais do que propor uma filosofia de caráter ou conteúdo democrático, praticava a democracia na forma mesma de seu filosofar, vivendo esse filosofar como uma ação entranhadamente democrática. É o caso, então, de colocar a democracia ateniense no banco dos réus, para submetê-la ao julgamento da História? Sem dúvida, ela errou, cometeu o terrível equívoco de condenar e executar um igual a ela, ferindo e contradizendo seus princípios mais fundamentais. Contudo, a autodefesa de Sócrates não referenda - ou sequer contempla - a hipótese de que houvesse um complô que comprometesse o regime democrático em sua condenação; rejeita inclusive a ideia de que o acusado estivesse sendo punido pelo que fora formalmente denunciado - para ele, o processo todo devia ser atribuído aos rancores suscitados pelo exercício de sua missão. Em suma, para o próprio Sócrates da Apologia platônica, não era por sua natureza ou funcionamento que a democracia ateniense o julgava e condenava, mas porque uma parte dos cidadãos não suportou, não aturou suas inquiriçōes epistemológicas e suas advertências ético-morais, além de deixar-se influenciar pela imagem de filósofo ímpio e corruptor dos bons costumes que dele projetou o cômico Aristófanes n'As nuvens.

A ideia que imputa à democracia ateniense a responsabilidade de haver assassinado seu incômodo filósofo é, segundo M. Finley (1991, p. 83-85), um "mito" criado "nas duas geraçōes seguintes" à de Sócrates por pessoas ligadas a ele e por outras "que se interessavam por filosofia". Para elas, a "acusação em si pode ter sido obra do acaso", mas "o que havia por trás dela não o era; era inerente a qualquer sociedade na qual o poder se concentrasse nas mãos de um grupo simplesmente por ser este o mais numeroso, o mais rico, ou detentor de outra qualificação puramente exterior". O "mito" embasaria e serviria à tese (platônica...) de que apenas "os virtuosos - os filósofos - devem governar; caso contrário, só podem sobrevir consequências maléficas”. Reconhecendo que a 
"execução de Sócrates é um fato, e é um de vários semelhantes que revelam que a democracia ateniense não era um instrumento perfeito", Finley argumenta que "também é um fato" o "caráter excepcional do caso de Sócrates na sua época", não podendo haver disso "melhor testemunha que Platão", uma vez que foi "em Atenas que ele trabalhou e ensinou, com liberdade e segurança, durante a maior parte de sua longa vida; e aquilo que ele ensinava era radicalmente hostil a boa parte das crenças mais caras aos atenienses. Ninguém o ameaçou ou coibiu."

É preciso acrescentar, parodiando o historiador, o fato de que, depois de Sócrates, nenhum outro pensador (incluso Platão) se aventurou e se atreveu a ser um filósofo público, um filósofo de praça pública, a exercer o filosofar como um direito e dever de cidadania e a cidadania como uma forma de filosofar: a filosofia, passando a constituir-se como corpo de ideias e doutrinas mais - ou menos? - que um agir cidadão, uma prática democrática, refugiou-se na escrita (inclusive literária ${ }^{17}$ ), nos guetos acadêmico-escolares e na teoria; iniciou aí um longo caminho para o isolamento e a solidão do filósofo, engendrando e sofrendo uma dicotomia (teoria versus prática) que, em Sócrates, teria sido simplesmente impensável e inviável.

A rigor, a expressão "em Sócrates" (chez Socrate...) já é uma espécie de licença poética, pois não remete a nenhuma obra, mas ao próprio existente, em que se fundem o pensar e o existir e, portanto, não deixa espaço para qualquer distância ou contradição entre o dizer, de um lado, e o agir, de outro: não se trata de apontar em Sócrates o exemplo vivo do que ele próprio diz e pensa, ou o modelo de coerência entre o falar e o agir, mas, uma vez que não escreve, nada há para exemplificar, não há qualquer relação que se possa estabelecer - distanciando-as - entre obra e vida; seu existir já é sua obra, isto é, o que ele faz e "deixa". E, ao tentar capturá-lo e retê-lo, a memória coletiva - o que chamamos de tradição - não obtém, no caso da História, mais que um enigma ${ }^{18}$ ou uma questão insolúvel ${ }^{19}$, e, no caso da filosofia, nada além de uma existência - ou melhor, um existente - que, em última instância, escapa à História ${ }^{20} \ldots$

17. Cf. Colli (I 988, p. 9- 10): "Platão chama 'filosofia' - o amor à sabedoria - à própria busca, à própria atividade educativa, ligada a uma expressão escrita, à forma literária do diálogo. [...] Por outro lado, a filosofia posterior, a nossa filosofia, é apenas uma continuação, um desenvolvimento da forma literária introduzida por Platão". Já Bakhtin (1981, p. 94) distinguia no gênero "diálogo socrático" um estágio oral, propriamente socrático, e a "fase literária", em que ele se torna "quase um gênero memorialístico: eram recordações das palestras reais proferidas por Sócrates".

18. Cf. Mossé, 1990, p. I57: "É preciso nos resignarmos a jamais conhecer o verdadeiro pensamento do filósofo Sócrates".

19. Cf. Dorion (2006, p. 25): "[...] nossa convicção de que a questão socrática não pode ser resolvida $[\ldots] "$

20. Cf. Brun (1984, p. 56), citando Kierkegaard [Post-scriptum aux Miettes philosophiques]: "A existência não existe; a existência é uma noção, o que existe é aquele tal sujeito existente. Se Sócrates é o

Pro-Posições, Campinas, v. 21, n. 1 (61), p. 107-125, jan./abr. 2010 


\section{Referências bibliográficas}

ARISTÓFANES. As nuvens. Trad. Gilda Maria Reale Starzynski. São Paulo: Abril, 1972.

ARISTÓFANES. As nuvens. Trad. Mário da Gama Cury. Rio de Janeiro: Jorge Zahar, 1995. ARISTÓTELES. A Constituição de Atenas. Trad. Francisco Murari Pires. São Paulo: Hucitec, 1995.

BAKHTIN, Mikhail. Problemas da poética de Dostoiévski. Trad. Paulo Bezerra. Rio de Janeiro: Forense-Universitária, 1981.

BRUN, Jean. Sócrates. Trad. Carlos Pitta. Lisboa: Dom Quixote, 1984.

COLLI, Giorgio. O nascimento da Filosofia. Trad. Federico Carotti. Campinas, São Paulo: Ed. Unicamp, 1988.

DORION, Louis-André. Compreender Sócrates. Trad. Lúcia M. Endlich Orth. Petrópolis, RJ: Vozes, 2006.

FINLEY, Moses I. “Sócrates e Atenas”. In: FINLEY, Moses I. Aspectos da Antiguidade. Trad. Marcelo Brandão Cipolla. São Paulo: Martins Fontes, 1991.

GUTHRIE, W. K. C. Os sofistas. Trad. João Rezende Costa. São Paulo: Paulus, 1995.

LAÊRTIOS, Diôgenes. Vidas e doutrinas dos filósofos ilustres. Trad. Mário da Gama Cury. 2. ed. Brasília: Ed. UnB, 1977.

MOSSÉ, Claude. Oprocesso de Sócrates. Trad. Arnaldo Marques. Rio de Janeiro: Jorge Zahar, 1990.

MOSSÉ, Claude. Atenas: a história de uma democracia. Trad. João Batista da Costa. 3. ed. Brasília: Ed. UnB, 1997.

MOSSÉ, Claude. Dicionário da civilização grega. Trad. Carlos Ramalhete. Rio de Janeiro: Jorge Zahar, 2004.

NIETZSCHE, Friedrich. Crepúsculo dos ídolos. Trad. Marco Antonio Casa Nova. Rio de Janeiro: Relume Dumará, 2000.

PLATÃO. Defesa de Sócrates. Trad. Jaime Bruna. São Paulo: Abril, 1972.

PLATÃO. Êutifron. Trad. Manuel de Oliveira Pulquério. Lisboa: Editorial Verbo, 1972.

PLATÃO. Sétima Carta. In: Diálogos. Trad. Carlos Alberto Nunes. Pará: Universidade Federal do Pará, 1975. v. 5.

PLATÃO. Criton. Trad. Manuel de Oliveira Pulquério. Brasília: Ed. UnB, 1997.

PLUTARCO. Alcibíades. In: Vidas paralelas. Trad. Gilson César Cardoso. São Paulo: Paumape, 1991. v. 2.

grande desconhecido da história, é porque o existente permanece profundamente incognoscível e porque toda a subjectividade é uma 'paixão do infinito'”. 
POPPER, Karl. A sociedade aberta e seus inimigos. Trad. Milton Amado. Belo Horizonte: Itatiaia; São Paulo: EdUSP, 1974. v. 1.

XENOFONTE. Apologia de Sócrates; ditos e feitos memoráveis de Sócrates. Trad. Líbero Rangel. São Paulo: Abril, 1972.

XÉNOPHON. Les helleniques. In: XÉNOPHON. Oeuvres completes. Trad. Pierre Chambry. Paris: Garnier-Flammarion, 1967, v. 3.

Recebido em 05 de agosto de 2009 e aprovado em 13 de novembro de 2009. 